\title{
保険金受取人に関する規定の理論的課題 とその検討
}

遠山聡

\section{ロアブストラクト}

保険金請求権が保険金受取人の固有の権利として原始取得されるという通 説・判例の考え方を前提とすれば，保険事故発生前の抽象的保険金請求権は どのように帰属していると考えるべきか。保険事故発生前において，保険契 約者（兼被保険者）は保険金請求権を遺贈の対象とすることはできず，質権 設定もできないと考えるのが整合的であるように思われるが，保険契約者は 保険金受取人変更による絶対的な処分権限を有しており，保険金受取人はあ くまでその変更が行われないことを前提とする弱い権利を有しているに過ぎ ないことから，保険金請求権の蚊渡・質権設定, そして放棄という各処分行 為を俯瞰すると，保険契約者による処分を相当程度認めることとなっており， 必ずしも理論的に一貫していない。

同様に，保険法は保険金受取人の変更に関して，法的安定性を重視して形 式要件を明確化しているが, 保険金受取人の変更, とりわけ遺言による変更 が行われた場合の有効性をめぐる紛争では，保険契約者の意思を尊重する観 点から柔軟な解決を図る余地も残されていないわけではなく, 両者のバラン スをいかに図るかは依然として重要な課題である。

\section{ロキーワード}

保険金請求権の処分，生命保険と相続，保険金受取人の変更

*令和元年10月26日の日本保険学会大会（関西大学）報告による。

/ 令和 2 年 3 月 27 日原稿受領。 


\section{1.はじめに}

平成20年の保険法制定にあたり，生命保険契約・傷害疾病定額保険契約の 分野においても，それまでの商法における規律の見直しがなされた。保険法 の条文の中には，いわゆる旧法主義をとるものも少なくなく，現段階での下 級審裁判例の多くは平成20年改正前商法（以下，「改正前商法」という）の 規定の解釈が必要となるが1)，保険法の制定にあたっても，大きな制度改正 が行われたことで，解橎問題が少なからず生じる可能性があることを示唆す る指摘もあったところであり ${ }^{2)}$ ，保険法施行後 9 年を経過して今後保険法の ルールでの解決へと移行する段階へと至るにあたって, 保険法の理論的側面 や実務対応の妥当性についてあらためて検証しておくことが望ましいように 思われる。本稿では，保険法施行前に締結された契約には適用されない生命 保険契約および傷害疾病定額保険契約に関する規律（いわゆる旧法主義）の うち，保険金受取人に関する諸規定を検討の対象として，従前の基本概念や 解釈などがどのように変化し，また維持されるべきものであるかという観点 から, これまでの裁判例や学説などを整理しつつ, 若干の検討を行う。

\section{2. 保険金請求権の処分}

\section{（1） 自己のためにする保険契約と第三者のためにする保険契約}

保険契約者（被保険者）と保険金受取人が異なる，いわゆる第三者のため にする生命保険契約は，第三者のためにする契約の一種ではあるが，保険法 42 条は，民法537条 3 項（平成29年改正前民法同 2 項）の一般原則を修正し て，保険金受取人は，受益の意思表示を要せず，当然に保険金請求権を取得

1）生命保険・傷害疾病定額保険分野では，保険給付の履行期や介入権などに関 する規定に新法主義が採られるほか（附則 2 条但書，3 条ないし 5 条），それ 以外の規定については, 経過措置としてその施行日以後に締結された保険契約 に適用される。

2）山下友信「保険法現代化の意義」ジュリ1368号68頁。 
する旨規定している。さらに，保険金受取人は，保険契約に基づく権利，す なわち保険金請求権を保険契約者から承継的に取得するのではなく, 自己固 有の財産として原始取得するのであり，保険金受取人として指定された者が 保険契約者兼被保険者の相続人であるような場合でも，当該保険金受取人は 相続によってではなく，あくまで固有の財産として原始取得すると理解する のが, 従来の判例であり通説である ${ }^{3)}$ 。これにより，保険金請求権は，保険 契約者兼被保険者の責任財産から離脱していると解して，保険金受取人であ る相続人が相続放棄や限定承認をした場合でも，被相続人である保険契約者 の相続債権者が保険金請求権を引当財産として強制執行することができない という帰結が得られる゙)。このように，第三者のための生命保険契約におい ては，とくに死亡保険金請求権について保険金受取人に対する専属性の強い 解釈が採られている。

保険金請求権は保険事故と同時に発生するものではなく，保険金受取人の 指定により条件付権利としての抽象的保険金請求権が保険金受取人に帰属し ているものと解されるので, 保険事故発生前の権利についても, 保険金受取 人が固有の権利として取得しているものと一応いうことができる。この抽象 的保険金請求権は，形式的には，保険金受取人に固有権として帚属するので, 保険契約者は保険金受取人の変更という手段によって，その帰属を変更しう るという形成権を有するに過ぎないのであり，保険金請求権に対しては，保 険契約者は保険金受取人の変更という方法を除けば，およそ他人の権利であ る保険金請求権に対する直接的な処分はできないということになる。しかし ながら，この抽象的保険金請求権は，保険契約者が，保険金受取人変更権を

3）大森忠夫 - 保険法〔補訂版〕275頁（有斐閣，1985年），西島梅治・保険法 〔第三版〕327頁（悠々社，1991年），山下友信・保険法508頁（有斐閣，2005 年）等。判例として, 大判昭和 11 年 5 月 13 日民集 15 巻 877 頁, 最判昭和 40 年 2 月 2 日民集 19 巻 1 号 1 頁。

4）解約返戻金相当額については，相続債権者のための責任財産に属するという 見解もある。大森忠夫「保険金受取人の法的地位」大森忠夫 $=$ 三宅一夫 ·生命 保険契約法の諸問題60頁（有斐閣，1958年）等。 
保険金受取人に関する規定の理論的課題とその検討

行使することにより簡単に移転されるものであるし，解約権の行使により消 滅させられてしまうものでもある（消極的には，保険料の不払いによる失効 も含む）のであるから，保険金受取人の権利は一種の期待権に過ぎないもの でもある ${ }^{5)}$ 。むろん, 保険事故発生後は, 保険契約者による変更権・解約権 を行使する余地はなく，保険金受取人の権利が確定する。

これに対して，保険契約者兼被保険者が自己を保険金受取人とする場合， いわゆる自己のためにする保険契約については，保険金請求権は相続財産に 帰属し，その相続人が承継取得することになると解されている。保険契約者 が意識的に自らを保険金受取人に指定する場合のほか，受取人の指定がなさ れなかったり，指定が公序良俗違反であること等によって無効となる場合も あるが，死亡保険契約では，抄よそ保険金請求権を保険契約者兼被保険者自 身が行使することはあり得ないから，実質においては，法定相続人を保険金 受取人とする第三者のためにする生命保険契約に類似する。自己のためにす る生命保険契約では，保険金が相続債権者の引当財産となるが，保険契約者 が積極的にそれを意図することは一般には考えられないから，特段の事情の 立証がないかぎり，保険金受取人を指定したものとして扱うべきであるとさ れるように れ $^{6}$ 保険契約者兼被保険者は，保険金請求権を自己の責任財産に 帰属させずに固有権として相続財産と分離するという解決が望ましいと考え るものという価值判断がはたらいている。

各種生命保険約款においては，保険金受取人の指定がない場合には，保険 契約者または被保険者の法定相続人を保険金受取人とする旨の規定が置かれ ることがある。この場合には，第三者のためにする生命保険契約となり，保 険金請求権は法定相続人の固有の財産となる。また, 保険金受取人の死亡後 に保険契約者兼被保険者が受取人変更をしないままに死亡した場合に，保険 金受取人の相続人が保険契約者兼被保険者であれば，保険金受取人の相続人

5）山下孝之·生命保険の財産法的側面50頁（商事法務，2003年），山下友信· 前掲注3) 541 頁，西島・前掲注3) 372 頁等。

6）山下友信・前掲注3) 491 頁。 
が新たな保険金受取人となるとする改正前商法676条 2 項（保険法46条）に よっても，そのかぎりで自己のためにする生命保険契約となるという解釈も とり得ないわけではないが, 判例 ${ }^{7}$ は，「指定受取人の法定相続人又はその 順次の法定相続人であって被保険者の死亡時に現に生存する者が保険金受取 人として確定する」という立場を採用して相続財産に帰属することを回避す る。その理由として「第三者を保険金受取人とする生命保険契約を締結する 者の現時の一般的意識を前提」とした保険契約者の意思解釈（最判平成 4 年 3 月 13 日民集 46 巻 3 号188頁），あるいは「保険金受取人が不存在となる事態 をできる限り避けるため, 保険金受取人についての指定を補充するもの」 （最判平成 5 年 9 月 7 日 47 巻 7 号 4740 頁）という点があげられている。

他方で，自己のためにする生命保険契約は，保険金請求権に対する質権を 設定する等，保険担保の目的で利用されることもあり，また，相続人不在に より保険者が保険金支払義務を免れることの不当性を指摘する見解もある 明示的に自己のためにする生命保険契約とする場合と，当初の受取人指定が なされていなかったり受取人指定が無効であるような場合とは区別されるべ きものかもしれないが，先に述べてきたような保険契約者の意思の推認は個 別具体的な事案において可能であっても，それを一般化することには疑問の 余地もあろう。

\section{（2）保険金請求権に対する質権設定}

改正前商法674条 2 項・ 3 項は, 保険金受取人が死亡保険金請求権を譲渡 する場合には被保険者の同意を要する旨規定する一方，質権設定については 明文の規定がなかったところ, 保険法 47 条は, 保険給付請求権の譲渡と並ん で質権設定についても被保険者の同意がなければその効力を生じない旨規定

7）大判大正11年 2 月 7 日民集 1 巻 1 号 19 頁，最判平成 4 年 3 月 13 日民集 46 巻 3 号 188 頁, 最判平成 5 年 9 月 7 日民集 47 巻 7 号 4740 頁等。

8）山下典孝「保険金受取人指定と保険金州属に関する一考察」生保論集161号 11頁以下。 
保険金受取人に関する規定の理論的課題とその検討

している。改正前商法とは異なり，譲渡や質権設定の主体を明示していない が，第三者のためにする生命保険契約において，保険金受取人は自己固有の 権利である保険金請求権につき譲渡や質権設定等の処分行為ができること自 体には争いはないものと思われる。

前述のように，この第三者である保険金受取人の権利は保険契約者の受取 人変更などによって容易に移転されてしまう権利であるし，保険契約者では ない保険金受取人が質権設定する場合でも，多くの場合，保険契約者兼被保 険者の同意が必要であることに加えて，債権者としてもあまり大きな意味が

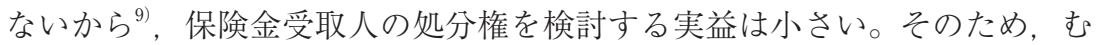
しろ保険契約者自身が，保険金請求権に質権を設定することができるかが従 来議論されてきたところである。民法362条 1 項は, 質権は, 財産権をその 目的とすることができるとしており，保険金請求権も債権質の一種としてそ の対象となりうるが，質権設定が有効であるためには，質権設定者が当該権 利に対する処分権を有していることが必要である。保険契約者が，保険金請 求権の処分権限を有するといえるかについては，学説や下級審裁判例におい て見解が対立している。

実務上は，生命保険契約に基づく死亡保険金請求権に質権を設定する場合， 保険契約者自身を保険金受取人に指定した上で，保険会社が作成した書式に より質権設定手続が行われるようである ${ }^{10)}$ 。問題は，第三者を保険金受取人 としたままで，保険契約者が保険金受取人の同意を得ることなく，質権を設 定することができるかである。立法担当者の解説によれば，質権を設定でき るのは，当然ながら当該保険金請求権を有する保険金受取人であり，保険契 約者が質権設定する場合には，自己を保険金受取人とすることが必要である

9）竹演修「第三者のためにする生命保険契約における質権設定者」立命館法学 $339 \cdot 340$ 号 135 頁。

10）系川厚生「生命保険と担保」担保法の現代的諸問題（別冊 NBL10号）173頁 (商事法務研究会, 1983年), 加藤昭「生命保険に基づく権利の担保化」ジュリ 964号56頁以下等。 


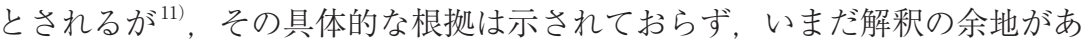
るように思われる。

第三者のためにする生命保険契約における保険金受取人の固有権性を強調 し，その専属性を強調すれば，保険金請求権は保険金受取人の権利であり， 保険契約者がこれを譲渡・質入れすることはできないということになる ${ }^{12)} 。$ 前述した実務上の取扱いからも保険実務はこのような立場を前提としている ように思われる。大阪地判平成17年 8 月 30 日 LEX/DB 文献番号25464329は, 保険契約者兼被保険者 $\mathrm{A}$ が相続人である B を保険金受取人として締結した生 命保険契約の保険金請求権につき，Aが質権設定を行った事案において，質 権の成立を否定している（ただし，BがAの債務を相続したとして原告らに よる貸金等の請求は認容した)。死亡保険金請求権が保険金受取人の固有の 財産であること，ならびに実質的に保険契約者・被保険者の財産に属してい たものとみることもできないことから，「死亡保険金請求権に質権を設定す るためには，死亡保険金受取人の質権設定行為が必要であり，死亡保険金受 取人の同意さえ不要であるとする原告らの主張は採用できない」というので ある。

他方，保険金受取人の有する保険金請求権が抽象的な期待権に過ぎないこ とを重視して，保険契約者による質権設定を認める見解も有力である ${ }^{13)}$ 。下 級審裁判例においても同様に，保険契約者の質権設定を肯定するものがある。 東京地判平成17年 8 月 25 日 LEX/DB 文献番号25464330は, 保険契約者兼被 保険者 $\mathrm{A} か ゙ ， Z$ を保険金受取人とする変額生命保険契約に基づく死亡保険金 請求権に質権を設定し，質権者が直接取立権の行使として死亡保険金を請求

11）萩本修·一問一答保険法191頁（商事法務，2009年）。

12）中西正明 - 生命保険法入門235頁（有斐閣，2006年），河合圭一「死亡保険金 請求権への質権設定について」金澤理監修・新保険法と保険契約法理の新たな 展開359頁（ぎょうせい，2009年），巻之内茂「保険契約と債権保全をめぐる諸 問題(中)」金法1416号29頁等。

13） 大森・前掲注3) 89頁，山下友信「生命保険契約にもとづく権利の担保化」現 代の生命・傷害保険法219頁（弘文堂，1999年）等。 
保険金受取人に関する規定の理論的課題とその検討

したという事案において，保険金受取人を変更できる以上，保険金受取人の 権利が確定するのは，Aが保険金を受け取るべき者を指定又は変更する権利 を行わずに死亡したときであり，A（保険契約者兼被保険者）の生前である 本件質権設定契約時には，Aは本件保険契約に基づく生命保険金の受取人を 変更することも可能だったのであるから，保険金受取人の権利は何ら確定し ていないことを理由として，「本件保険契約に基づく死亡保険金について質 権設定する本件質権設定契約において，その契約締結につき，当時生命保険 金受取人としての具体的権利を有しているとはいえない Z の同意を得ること が，契約が有効に成立するための要件となるとは解されず，また，保険金受 取人の権利が優先すると解すべき理由はない」と判示した。

また，東京地判平成22年 1 月28日判夕1359号211頁も同様に，保険契約者 による質権設定を肯定する。同判決は，保険事故が発生するまでは保険契約 者が処分権を有し，「保険契約者が第三者を受取人とする保険金請求権に質 権を設定することによって，これを処分することも可能である」とした。そ の控訴審判決である東京高判平成22年11月25日金判1359号50頁 ${ }^{14)}$ においても この立場は維持されている。保険事故発生前の具体化していない保険金請求 権については，保険契約者が一定の処分権を有しており，保険契約者の財産 権に属するものという理解を前提に，「保険契約者は，死亡保険金の受取人 として指定した者の承諾がなくとも死亡保険金請求権について質権を設定す ることができるものと判断すべきである」と判示した。

保険事故の発生により具体化した保険金請求権が保険契約者の遺産から離 脱した保険金受取人の固有の財産となり，もはや保険契約者の処分権は及ば

14）評釈として，桜沢隆哉「判批」事例研レポ 252 号 13 頁, 井上健一「判批」ジ ユリ1431号152頁，中込一洋「判批」事例研レポ255号 1 頁，天野康弘「判批」 共済と保険2012年 2 月号38頁, 佐野誠「判批」福岡大学法学論叢56巻 2 - 3 号 277頁, 岡田豊基「判批」私法判例リマークス44号102頁，山下典孝「判批」ジ ユリ1440号108頁，田爪浩信「判批」法律のひろば65巻 6 号65頁, 金尾悠香「判 批」法学研究 85 巻 5 号33頁, 小林道生「判批」法学教室別冊378号21頁, 田中 秀明「判批」金判1386号68頁，山下徹哉「判批」商事法務2040号105頁。 
ないということはいえるとしても，抽象的保険金請求権は，保険契約者の管 理を前提とした生命保険契約上の利益の一つに過ぎない ${ }^{15)}$ 。たしかに，保険 契約者と保険金受取人のいずれもが同一の保険金請求権に対して質権を設定 できるとすることは実務上の問題を生じさせる懸念もある。たとえば，保険 金受取人と保険契約者のそれぞれが別個に質権設定をしている場合には，そ の優先性が問題となることや，保険者の二重払いのリスクが増大する，受取 人と質権者との間の紛争が生じるなどのリスクが生じうるが ${ }^{16)}$, 東京高判平 成22年も指摘しているように，保険金請求権につき保険契約者による質権設 定を制限する必要があるのであれば，約款にそのような規定を置くことによ って対処できる。

\section{（3） 保険金請求権の贈与・遺贈}

保険金受取人は，抽象的権利である保険事故前の保険金請求権を自ら他に 譲渡できるか。改正前商法（674条 2 項， 3 項）と同じく, 保険法も, 保険 事故発生前の保険金請求権の譲渡ができることを前提としており（47条）， これを認める考え方が支配的である ${ }^{17)}$ 。この立場を前提とすると，保険金受 取人が保険金請求権を譲渡したとしても，保険契約者が保険金受取人自体を 変更した場合には，譲受人の権利は消滅するものと考えざるを得ないであろ うが，保険金受取人の死亡について定める保険法46条との抵触はなお問題で ある。保険法46条（改正前商法676条 1 項も同様）が保険金受取人の死亡に よって，その相続人が新たな保険金受取人となり，保険金請求権を原始取得

15）保険契約者は，受取人変更や解約などの手段により，一定の処分権を及ぼす ことができるという点で違いがある。

16）巻之内・前掲注12) 29頁, 天野・前掲注14)74頁等は, 肯定説による保険会社 の支払い事務, 紛争の原因となる懸念を指摘する。債権取立てのためのモラル リスクの懸念を指摘するものとして, 甘利公人「傷害保険と質権設定」石田満 編・保険と担保320頁以下 (文眞堂, 1996年), 松田武司「生命保険契約の担保 利用」産大法学 40 巻 2 号 55 頁以下等。

17）山下友信・前掲注3) 541頁等。 
する旨規定していることを前提とすれば，抽象的な保険金請求権は相続の対 象とはならないが, 保険金受取人が行った生前の処分行為がその死亡によっ てすべて無効となると解してよいか。

東京地判平成24年 8 月 21 日 LEX/DB 文献番号 $25496181^{18)}$ は, 保険金受取 人 A （保険契約者兼被保険者はB）が，すべての遺産をCに相続させる自筆 証書遺言をしたという事案において，保険契約者は，受取人を自由に変更で きること，保険会社の承諾があれば，保険契約上の権利義務を第三者に承継 できることを理由として，「Aが死亡時に有していたのは，Bが自由に受取 人を指定変更することにつき，何らの異議を述べることもできず，抽象的死 亡給付金請求権について何の処分権もない受取人の地位にすぎないのである から，これが，Aの相続財産を構成する財産であるとはいえず，これを保険 契約者ではないAが遺言により第三者に移転することができないことは明ら かである」とし，さらに，改正前商法676条 2 項，保険法46条（75条）のい ずれも，受取人の地位ないし抽象的死亡給付金請求権が被保険者が死亡して 保険金請求権が発生するまでは，指定受取人の相続人に相続されるべき財産 ではないことを前提としていることを理由として，「指定受取人が遺言によ り相続させることができる財産に，受取人の地位ないし抽象的死亡給付金請 求権は含まれていないというべきである」と判示する。同判決は，保険金受 取人の処分権を否定して, 保険金受取人による保険金請求権の遺贈の効果を 否定しているため，保険金受取人に処分権があることを前提とした場合の， 保険法46条との関係については問題として残ることになる ${ }^{19)}$ 。

18）評釈として，原弘明「判批」事例研レポ271号11頁，梅津昭彦「判批」事例 研レポ272号 1 頁。

19）東京地判平成24年 2 月 23 日 LEX/DB 文献番号25461762は, 前掲東京地判平 成24年 8 月 21 日と同様に，保険金受取人Aが自筆証書遺言により財産全部を保 険契約者（兼被保険者）Bに遺贈し，Bの相続財産を承継したXが保険金請求 権はBの相続財産に帰属するとの主張に対して, 改正前商法676条 2 項の規定 に従い，Aの法定相続人が保険金受取人になるとして，請求を棄却した（ただ し，遺贈の効力を否定したものであるかは明確ではない)。 
保険法46条は，いわゆる第三者のためにする生命保険契約において，受取 人が保険事故発生前に死亡したにもかかわらず保険契約者が受取人を変更し ないまま保険事故が発生した場合に，受取人が不在となる状態を回避するた めに設けられた規定であると解されている ${ }^{20)}$ 。そうすると，保険金受取人が 生前の処分として贈与や遺贈をした場合には, 保険金請求権者が不在となる わけではないため，保険金受取人の処分を優先させる（つまり，保険法46条 は適用されない）という解釈もできなくはないが，少なくとも相続関係者の 実態としては，保険金受取人の処分行為を無効とすることが妥当である場合 が多いように思われる ${ }^{21)}$ 。

\section{（4）保険金請求権の放棄}

保険金請求権が保険金受取人に帰属する以上，保険事故の発生により具体 的な金銭債権と化しているか否かを問わず，保険金受取人による任意の処分 ができるという前提にたつとき，保険金受取人による保険金請求権の放棄の 効果が問題となる。

第三者のためにする契約につき，民法は，第三者のためにする契約におけ る第三者の権利は，その第三者が債務者に対して契約の利益を享受する意思 を表示した時に発生する（民法537条 3 項）旨規定するとともに，これによ り第三者の権利が発生した後は，当事者は，これを変更し，または消滅させ ることができない（民法538条 1 項）旨規定する。保険法42条（改正前商法 675条 1 項）は，第三者のためにする生命保険契約において，保険金受取人 は当然に保険契約の利益を享受するとして，受益の意思表示を不要とするが, 保険金受取人に指定された第三者が受益を拒絶する場合に，諾約者である保

20）前揭最判平成 5 年 9 月 7 日，萩本・前掲注11) 188頁以下。

21）梅津昭彦「判批」事例研レポ 9 頁〔山下友信教授コメント〕は，いわゆる指 定失効説と指定非失効説のいずれをとっても，指定受取人が遺贈した保険金請 求権者の地位は, 改正前商法676条 2 項により, 指定受取人の死亡により直ち に消滅するとされる。 
保険金受取人に関する規定の理論的課題とその検討

険者の債務が消滅するかはなお明らかではない。

保険金受取人は，当然に（受益の意思表示を必要とせず）生命保険契約上 の利益を享受するが，受益者が無理やり受益を押しつけられるのは妥当でな いとする一般原則からすれば，保険金請求権についても当然にこれを放棄で きることになる。保険金受取人による権利放衰は，保険事故の前後で区別さ れるところ，保険金受取人が保険事故発生前に保険金請求権を放棄した場合 には，保険金受取人の指定がない契約となり，自己のためにする生命保険契 約となると解されている 22 。しかしながら，保険事故発生前に保険金受取人 が明示的に権利放衰することは想定しにくいし，仮にそのような場合があっ ても，保険契約者は保険金受取人の変更手続をすればよいだけであるから， 問題状況としては顕在化しにくい。

むしろ現実に問題となるのは，保険事故発生後に保険金請求権を放棄した 場合である。保険契約者兼被保険者の相続人が，保険金受取人が取得するは ずであった保険金は相続財産に属するものとして，保険者に対してその支払 いを求めるケースであり ${ }^{23)}$, 保険金受取人である相続人が被相続人との一切 の関わりを拒絶するという流れで，相続放衰や保険金請求権の放棄をすると いう事案も少なからずあるようである ${ }^{24)}$ 。学説には, 保険事故発生前におけ るのと同様，自己のためにする生命保険契約となり，保険者は保険契約者兼 被保険者に対して保険金支払義務を負うとする見解 (自己契約説) ${ }^{25)}$ と，保 険金請求権は権利放棄により確定的に消滅するとする見解（債務消滅説）が ある。

22）大森 - 前掲注3) 60頁等。

23）後掲のとおり, 大阪高判平成11年の事案のようにすべての保険金受取人が放 棄する場合と，大阪高判平成 27 年の事案のように，一部の保険金受取人が放棄 する場合が想定される。

24）中村敏夫「保険金受取人の受益の拒絶」生命保険契約法の理論と実務193頁 (保険毎日新聞社, 1997年)。

25）出口正義「判批」損保研究 61 巻 4 号 151 頁以下, 遠山優治「保険法における 保険金受取人の権利一その取得と放棄について一」保険学雑誌613号108頁以下。 
従来公表されている下級審裁判例においては，ほぼ債務消滅説で一致して いるように思われる。京都地判平成11年 3 月 1 日金判1064号40頁は，第一順 位の相続人である保険金受取人が相続を放棄した後，保険金請求権をも放棄 したことから，次順位の法定相続人が保険金請求をしたという事案において， 保険金請求権は，通常の債権と同様に，保険金受取人はこれを自由に処分す ることができ，保険金受取人がこの請求権を放棄すれば，保険金請求権は確 定的に消滅したというほかないと結論づけた。控訴審判決である大阪高判平 成11年12月21日金判1084号44頁 ${ }^{26)}$ もこれを引用する形で結論を維持してい $ろ^{27)}$ 。

また，神戸地尼崎支判平成26年12月16日判時2260号76頁は，「被保険者の 死亡により保険金請求権が具体化した後に，保険金受取人として指定された 相続人が被保険者の相続について相続放棄をしたとしても，相続放棄の事実 は，当該相続人の固有財産としての保険金請求権の得喪に影響するものでは ないから，相続放棄により，その者が取得した保険金請求権が当然に他の相 続人に帰属することにはならない」としたうえで，「相続債務の額が積極財 産の額を上回る場合以外にも様々な理由で相続放棄がされている実情等に照 らすと，第一順位の相続人中に相続放棄した者と相続放棄しなかった者とが いる場合に，相続放棄をした者を保険金受取人から除外することが，保険金 受取人を『法定相続人』と指定した保険契約者の通常有する合理的意思であ るということはできず，むしろ，保険契約者は，別段の意思表示がない限り， 保険事故が発生した後，各法定相続人が取得した具体的な保険金請求権の行 使や処分を各人の自由意思に委ねたものと推認されるのであり，保険金受取 人として指定された相続人のうちの一部の者が, 保険事故発生後, 自己の保 険金請求権を他の第一順位の相続人に譲渡するのではなく，あえて保険金請

26）評釈として，笹岡愛美「判批」保険法判例百選（別冊ジュリ202号）142頁， 広瀬裕樹「判批」名古屋大学法政論集190号355頁。

27）ただし，保険金受取人が権利放棄した時点で約款所定の時効期間が経過して おり，保険者は時効消滅を主張することも可能であったという事案である。 


\section{保険金受取人に関する規定の理論的課題とその検討}

求権放棄等の意思表示をした場合に，当該相続人の意思に反してその者の保 険金請求権を他の第一順位の相続人に取得させることが，保険契約者の通常 有する合理的意思であるということもできない」と判示した。

その控訴審判決である大阪高判平成27年 4 月23日2015WLJPCA04236005 ${ }^{28)}$ も，基本的に原審と同様の判断であるが，「生命保険契約における保険金受 取人の指定には保険契約者が保険者を相手方としてする意思表示であるから， これによって保険契約者が何人を保険受取人として指定したかは，保険契約 者の保険者に対する表示を合理的かつ客観的に解釈して定めるべきものであ って，仮に，保険契約者が生きていて，保険事故発生後に生じた事情を知っ たならば，保険金を誰に受領させたいと望むと考えられるかといった保険契 約者の内心の心情等を推し量って解釈すべきものではない」との判断を追加 している。自己契約説の中心にあるのは，保険金請求権の放棄が反射的に保 険者に利得を生じさせる結果となる不合理を受け入れ難いという価值判断が あり，保険金受取人の権利放棄によって，誰にも保険金が支払われないこと は避けたいという保険契約者の意思の推測に基づいている ${ }^{29)}$ 。その論拠とし ては，もともと保険金受取人の指定は，保険金受取人が権利放棄する場合に は保険契約者を保険金受取人であるとする趣旨でなされたものであるという 構成や ${ }^{30)}$, 保険金受取人の権利放棄は, 通常, 権利者としての地位を認めた うえでの債務免除ではなく，権利者となること自体の放棄であって，別段の 意思表示がないかぎり債権は消滅せず，受取人の指定が無効となる結果，自

28）最判平成27年10月 8 日2015WLJPCA10086008（上告不受理決定）。評釈とし て, 田中壯太「判批」NBL1062号70頁，水野貴浩「判批」金判1486号104頁， 牧純一「判批」共済と保険2016年 8 月号22頁, 広瀬裕樹「判批」事例研レポ 301号14頁，西原慎治「判批」私法判例リマークス53号94頁，山下友信 $=$ 米山 高生編 ·保険法解説一生命保険・傷害疾病定額保険295頁以下〔山野嘉朗〕（有 斐閣，2010年)。

29）山下友信・前掲注3) 509頁，広瀬裕樹「生命保険契約における死亡保険金請 求権の放棄一近時の裁判例を踏まえた分析一」生保論集207号81頁。

30）山下友信・前掲注3)509頁。 
己のためにする契約に転化するという構成 ${ }^{311}$ が採られている。

しかしながら，保険金請求権の固有権性を強調して，保険金受取人は，保 険事故の発生により具体化した保険金請求権を確定的にすると解する以上, これを放棄することにより保険契約者の責任財産に「返還される」という効 果は論理として一貫しないし, 保険金受取人が権利行使と放棄のいずれも行 わず時効により保険金請求権を行使しないままに消滅させてしまう場合には, 同じく保険者が利得する結果となるが，それも保険金受取人の任意の処分に よるものというほかない。たしかに，保険者を結果的に免責となってしまう ことが不合理であり，誰かに保険金が支払われることが望ましいことはいう までもない。そのための調整として保険料積立金の払い戻しを認める見解も ある ${ }^{32)}$ が，解釈論として自己契約説を採ることにはやはり疑問があり，立法 論としての解決が必要であるように思われる ${ }^{33)}$ 。

\section{3. 保険金受取人の変更}

\section{（1）改正前商法と保険法の規律の相違点の確認}

改正前商法675条 1 項は, 保険契約者には保険金受取人の変更権限がない こと（同本文）を原則としつつ，その権限が留保されること（同但書）を認 める構成を採用していたが，生命保険契約は，通常，長期間にわたって継続 される契約であることから，保険期間中の事情変更によって保険金受取人を 変更することが必要な場合が少なくなく，実務上は，約款において，保険金 受取人の変更権が留保されるのが一般的である。受取人変更の方法について

31）竹漕修「判批」事例研レポ153号 4 頁〔中西正明教授コメント〕。この他，中 村・前掲注24)194頁，笹本幸祐「生命保険契約の保険金受取人の権利取得と放 棄」倉沢康一郎先生古希記念・商法の歷史と論理356頁以下（新青出版, 2005 年), 同「生命保険契約の保険金受取人の権利取得と放棄再論一大阪高判平成 27 年 4 月 23 日平 27 (ネ) 208 号を素材として一」生保論集196号123頁等。

32） 竹演 ·前掲注31) 3 頁。

33）ドイツ保険契約法 160 条 3 項のように，保険金受取人が保険金請求権を取得 しない場合には，契約者が権利取得する旨を規定する立法論がありうる。 
保険金受取人に関する規定の理論的課題とその検討

は，同条にはなんら規定がなく，最判昭和62年10月29日民集41巻 7 号 1527 頁 は，「保険契約者がする保険金受取人を変更する旨の意思表示は，保険契約 者の一方的意思表示によつてその効力を生ずるものであり，また，意思表示 の相手方は必ずしも保険者であることを要せず，新旧保険金受取人のいずれ に対してしてもよく，この場合には，保険者への通知を必要とせず，右意思 表示によつて直ちに保険金受取人変更の効力が生ずるものと解するのが相当 である」と判示して, 変更方法に関する解釈を示した。この考え方は, 以降 の裁判例はもちろん，学説においても概ね支持されてきた ${ }^{34)}$ 。保険者が負う 二重支払いのリスクについては，保険契約者の保険者に対する通知を，保険 金受取人変更の保険者に対する対抗要件とすることで考慮されている（改正 前商法677条 1 項)

そもそも生命保険契約において誰を保険金受取人とするかは，保険契約者 の意思にかかわるものであり，保険者が利害関係を有するとしても，それは 保険金受取人の指定・変更の対抗要件とするだけで十分であると指摘された ように ${ }^{35)}$ ，この最判昭和 62 年の考え方をさらに敷衍していけば，相手方のな い意思表示と解して，保険者や新旧受取人に到達することも不要であるとい う考え方にいきつく ${ }^{36)}$ 。前提となるのは，できるかぎり保険契約者の意思を 反映すべきという価值判断であり ${ }^{37)}$, 保険金請求権の帰属につき柔軟な解決 を図ろうとするものである。他方で，このような最判昭和 62 年をべースとす る考え方に対しては，有力な批判も提示されていたところである。すなわち， 保険金受取人の变更については，指名債権譲渡の確定日付による対抗要件の ように，意思表示の有無や先後を明確にして権利の帰属を明確化する仕組み がないために，保険金受取人の変更が競合する場合や差押債権者等の第三者

34）大森 - 前掲注3)279頁, 石田満・商法IV（保険法）〔改訂版〕291頁（青林書 院，1997年），西島・前掲注3)336頁，山下友信・前掲注3)497頁等。

35）石田・前掲注34) 291頁。

36）山下友信・前掲注3) 497頁。

37）大森忠夫「保険金受取人指定 - 変更 ·撤回行為の法的性質」大森 $=$ 三宅一 夫・生命保険契約法の諸問題（有斐閣, 1958年), 山下友信・前掲注3)498頁等。 
が関与する場合に，法律関係が不安定になることが懸念され，意思表示の相 手方を保険者に限定すべきというものである ${ }^{38)}$ 。

これに対して，保険法43条は，保険契約者の保険金受取人変更権限が留保 されることを原則として（同１項），その方法として１「保険者に対する意 思表示」（同 2 項）と，(2)「遺言」（44条 1 項）によることを法定し, 法律関 係の安定に資する規律にシフトしたが，保険法施行後の契約においても通知 や遺言の有効性が争われるケースは依然として少なくないものと思われる。 (1)については，保険者に対する意思表示があったといえるか否か ${ }^{39)}$ ，意思表 示の通知が「発した」あるいは「到達」したと評価できるか否か等が，解釈 問題として残る。(2ににつても，とりわけ，従前の下級審裁判例においては， 保険金受取人の変更を相手方のない意思表示と解し，できるかぎり柔軟に保 険契約者の真意を探求するという立場を前提として, 遺言による受取人変更 を認めてきたものであり，遺言の解釈においても後述のとおり，客観的な基 準によりながらも，比較的柔軟な解釈基準が採用されてきた。遺言の内容か ら保険金受取人が誰であるか判断が難しい場合には，債権者不確知として供 託することも検討される余地があるものの ${ }^{40)}$ ，このような解釈基準が，法的 安定性の確保を重視する保険法の規律においても維持されるかは見解が分か れるものと思われる。

38）藤田友敬「判批」法協 107 巻 4 号708頁以下。

39）とりわけ意思能力の有無についての判断は, 高齢化社会の進展に伴い, ます ます深刻化しうる。岡田豊基「保険金受取人変更時に求ける保険契約者の意思 能力の有無」神戸学院法学 47 巻 $2 \cdot 3$ 号 1 頁, 野口夕子「保険金受取人変更の 意思表示一かかる行為の性質と保険契約者の意思能力」近大法学 66 巻 $3 \cdot 4$ 号 41頁。

40）大串淳子 - 日本生命保険生命保険研究会編 - 解説保険法153頁以下〔渡橋健〕 (弘文堂, 2008年)。 
保険金受取人に関する規定の理論的課題とその検討

\section{（2）保険契約者の意思をどこまで探求すべきか}

改正前商法においては，そもそも保険金受取人変更については，口頭での 意思表示も有効であり，かつ，明示的なものに限らず黙示的なものでもよく， 保険者や保険金受取人の同意がなくても効力を生じるが，この場合でも，意 思表示として確認される事実が必要であるというのが通説的な見解である ${ }^{41)} 。$ 受取人変更の意思表示の有無については，保険者に対する受取人変更手続が 未了である状態で被保険者が死亡したという事案において，保険契約者の 「最終的かつ確定的意思」を要求するのが一般的傾向である。保険金受取人 変更請求書を取り寄せたものの，いまだ提出に至っていない場合には，「最 終的かつ確定的な意思表示」がなされたものではないとして受取人変更の効 力を否定した事例がある ${ }^{42)}$ 。

他方で，保険法44条 1 項のような明文の規定がなかった改正前商法下では, 保険契約者の「最終的かつ確定的な意思表示」であることが確認されること を条件に遺言による受取人変更を認める事例があり，保険契約者の意思をで きるかぎり尊重すべきものとされてきた ${ }^{43)}$ 。東京地判平成 9 年 9 月 30 日判夕

968号130頁（控訴審：東京高判平成10年 3 月 25 日判夕 968 号 129 頁) ${ }^{44)}$ は, 遺

41）大森·前掲注3)279頁，石田・前掲注34)290頁等。

42）東京地判平成18年 1 月 16 日生保判例集18巻31頁（山下典孝「判批」事例研レ ポ209頁 9 頁), 宮崎地判平成28年 2 月 29 日2016WLJPCA08296005（控訴審福 岡高宮崎支判平成29年 6 月 7 日2017WLJPCA06076008も同旨, 上告審である 最判平成29年11月 7 日2017WLJPCA11076010は上告棄却・上告不受理決定。 板東大介「判批」事例研レポ324号11頁, 得津晶「判批」事例研レポ323号 1 頁)。

43）京都地判平成18年 7 月 18 日生保判例集 18 巻489頁（山下典孝「判批」金判 1250号43頁）は，自己を被保険者とする養老保険契約（受取人無指定）につき 公正証書遺言により，保険金が法的に遺産に含まれるか否かを問わず，Aが所 有していた一切の財産をXに取得するつもりで, 本件保険金についても受取人 としてXを指定したと認定したうえで,「その意思表示の明確性まで要求しな ければならない必然性はそしく…公正証書遺言によってなされた保険契約者の 最終的・確定的意思を尊重しない結果となるのは妥当とはいえない」と判示し た。

44）評釈として，山本哲生「判批」平成10年度重要判例解説（ジュリ1157号） 
言による変更の有効性が争われた事案において，「保険契約者の日記にその 旨が記載されたにすぎない場合や，手紙の下書きにその旨の記載がある場合 のように，意思表示が確定的に成立しているとはいえず，単に受取人変更の 意思がうかがい知れるというにすぎない場合には，受取人変更の意思表示が あったものということはできない。意思表示といえるかどうか明白でないも のについてまで意思表示といえるかどうかを探究しなければならないとした 場合，保険金の受取人が誰であるかをめぐって深刻な争いが生じかねないの であり，意思表示が確定的に成立していることは，保険金受取人変更の意思 表示といえるための必須の要件である」として，遺言において意思表示が確 定的に成立していることを理由として, 受取人変更の効力を認めている。控 訴審である東京高判平成10年 3 月 25 日判夕968号129頁も同様に,「その意思 表示（効果意思の表示）が外部から明確に確認できるものである限り，単独 の意思表示としてすることも許容すべきである」と判示して, 原審の判断を 維持している。

保険法 43 条 2 項および44条 1 項に定める変更方法は，いずれも形式的な手 続が要求されるものであるため, 一般的には, 保険契約者の最終的かつ確定 的意思を明確に確認できる方法であるといえよう。しかしながら，保険者へ の通知（具体的には, 変更請求書の交付）や形式的要件を具備した有効な遺 言がなされる場合であっても，それが保険契約者の最終的かつ確定的意思に よるものであるのかについて，保険契約者の受取人変更の内容が自然で，か つ合理的であるかという点から，保険契約者の意思を客観的に解釈すること が必要になる ${ }^{45)}$,46)。

112頁，山下典孝「判批」金判1050号57頁，岡田豊基「判批」事例研レポ137号 1 頁，長谷川仁彦「判批」法律のひろば 60 巻 4 号 72 頁等。

45）認知症のある保険契約者兼被保険者が，74歳であり意思能力に減退があるこ とは否定できないものの，看護師との間に意思疎通が成立していること，受取 人変更は同人から新受取人（内縁の妻）に積極的にはたらきかけていること, 死亡保険金は葬儀関係費用に充てられることが予定されており，喪主となる者 を受取人とするものであったこと，11年間にわたり実質夫婦として生活し，入 
保険金受取人に関する規定の理論的課題とその検討

\section{（3）通知による変更}

(1)約款に基づく変更手続と強行規定性

立法担当者によれば, 保険法43条 2 項および 3 項は, 性質上強行規定であ る ${ }^{47)}$ 。保険法43条 2 項が強行規定であることを前提として，これをどこまで 加重することが許容されるかが問題となり，他方で，同要件を満たさない受 取人変更の「通知」が有効であると評価されるべきかも問題となる。かかる 条項が，法律関係を明確化させるという保険者側の便宜にあることはいうま でもないが，手続要件を厳格にすれば，不明確な状態は回避できるが，保険 契約者の意思の尊重が後退する可能性がある ${ }^{48)}$ 。むしろ保険契約者に慎重な 判断を求めることで保険契約者の利益に資するとする指摘 ${ }^{49)}$ もるる。

まず，手続要件の加重についてはどうか。保険法施行後の生命保険各種約 款においては，「会社に対する通知」を要件とするのみで，保険者の同意を 要件としていないものが多い ${ }^{50)}$ 。従前の約款のように，保険者の同意を要件 としている場合に，保険者はその同意がないことを理由に，変更の効力を否

院時にはその面倒を見ており，内縁の妻を受取人にすることは「極めて自然な こと」であること, 受取人変更は格別難しい意味を持つものではないこと等か ら，意思能力があったことを認めた事例がある（金沢地小松支判平成26年 9 月 2 日2014WLJPCA09026004)。

46）保険金受取人無指定の生命保険契約につき（指定がない場合には，被保険者 の遺族を死亡保険金の受取人とする旨の約款規定があり），保険契約者兼被保

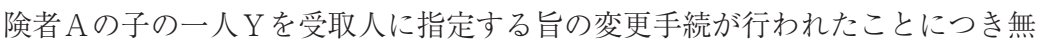
断変更の有無が争われ，手続きの必要性や理由がないことなどから，無断手続 により保険金を取得したとして不法行為に基づく損害賠償義務を認めた事案 （東京地判平成29年 9 月28日2017WLJPCA09288025）がある。

47）萩本·前掲注11) 181頁。

48）深澤康弘「保険金受取人変更の効力発生に関する一考察一米国の判例法を参 考に一」生保論集179号190頁。

49）得津・前掲注42) 14頁。

50）共済では，その制度趣旨から保険金受取人の変更につき，保険者の同意を要 求する場合があるとされる。山本哲生「保険金受取人の指定・変更」甘利公人 =山本哲生編・保険法の論点と展望270頁（商事法務，2009年）。 
定できるか。この点については，保険法43条 2 項は，意思表示の相手方およ び効力について強行規定であるものの, 保険者に対する意思表示という点さ え守られていれば，それ以外の点で変更要件を加重することは必ずしも強行 規定性に反しないとして, 有効性を認められるといえるかが問題となる。こ の同意に関しては，保険者に保険契約者による受取人変更の意思表示があっ たか否か, あるいはその意思能力の有無につき確認の機会を与えることを理 由として，保険者に自由裁量を認めるものではないとする見解がある ${ }^{51)}$ 。受 取人变更に同意しないことにつき合理的な理由がないような場合には，受取 人変更の効力を否定することはできないと解すべきであろう。

次に, 約款上の手続要件を満たさない意思表示の有効性についてはどうか。 通常，保険金受取人の変更には，保険会社が定めた書式が用意されるものと 思われるが, このような書式を用いていない場合や，書類に不備がある場合 など, 受取人変更の効力が生じないと解することができるか。手続の明確化 や受取人変更をめぐる紛争の防止などの観点からは，保険会社所定の変更請 求書等の書式によることが望ましいであろうし，保険契約者に過度の負担を 強いるものではないかぎり許容されるとする見解がある ${ }^{52)}$ 。しかしながら， それが，他の方法による通知を排除する趣旨であれば，強行規定性への抵触 の問題が生じうる。保険法43条 2 項は「保険者に対する意思表示」を要件と し，それ以外の要件をとくに定めていないから，書式要件を満たしていない が意思表示としては明確に認知できる場合にまで, 意思表示を一切認めない と解することはできないように思われる年)。

たとえば, 電話や営業職員に対して口頭で受取人変更の意思を伝えたに過 ぎない場合はどうか。約款上は，告知についても告知書による質問について は書面で告知すべきことを要求し，告知受領権は営業職員に与えておらず,

51）得津 · 前掲注42) 15頁。

52）前掲注40)解説保険法143頁以下〔渡橋健〕，山下典孝「保険法における保険 金受取人に関する一考察」生保論集167号133頁。

53）得津 · 前掲注42) 14頁以下。 
保険金受取人に関する規定の理論的課題とその検討

営業職員に対して口頭で告知をしても有効な告知とは認められないこととの 平大として, 通知受領権についても，営業職員には与えられていないことを 前提に，有効性を否定する考え方もありえようが，受取人変更手続における 通知受領権については, 必ずしもこれと同様に解する必要はなく, 営業職員 に対して口頭で通知しただけであっても，それが保険契約者の最終的かつ確 定的な意思であることが客観的に明らかであるような場合には，有効な意思 表示と認めてもよい場合があり得る。

(2)保険者に対する通知の「発信」および「到達」

保険法 43 条 3 項本文は，受取人変更通知が保険者に到達したときは，当該 通知を発した時にさかのぼってその効力を生ずると規定する。相手方のある 意思表示の場合，民法97条 1 項の原則では到達をもって意思表示の効力が生 じるところ，到達を条件とする発信主義に修正されたものである。その但書 において，その到達前に行われた保険給付の効力を妨げないとして，保険者 の免責を定めている。保険者の二重払いのリスクを考慮したものである。立 法担当者の解説によれば，改正前商法の判断枠組みでは，保険者に対して対 抗要件（商法677条 1 項）を具備しない場合には，保険者は変更前の保険金 受取人に保険金を支払えば足りるが，変更自体は効力を生じているため，保 険金を受領した保険金受取人に対して不当利得返還請求ができることになり， 「法律関係をいたずらに複雑化させる」ことになる ${ }^{54)}$ 。そのため, 保険者と の関係と新旧保険金受取人間において，権利の帰属が異なるということはで きるかぎり回避すべきであることが求められる。問題は, その要請と保険契 約者の最終的かつ確定的意思の尊重をどこまで調整できるかである。

通知の「発信」および「到達」の有無が問題となるケースとしては，保険 者の定めた書式に従って手続書類を作成し，発送手続を完了した場合に「発 信」要件を満たすとして，これまで取り上げた裁判例においてみられるよう

54）萩本·前掲注11) 181頁。 
に，高齢の保険契約者が親族に書類の作成を（代筆を含めて）依頼したり， 自ら郵送手続をとることができない場合に保険会社の営業職員に対して手渡 すような場合が考えられる。保険契約者の支配領域内から離れ保険者に向か って発せられているから「発信」と解することができる55)，あるいは，営業 職員が遅滞なく伝達してくれるものと期待するのが通常であるとして, 営業 職員に対して書類を交付した時点で到達があったと解すべきである ${ }^{56)}$ との見 解がある。保険契約者の最終的かつ確定的な意思が客観的に明確であること を条件として，保険者に向けられた意思表示が通常到達することが合理的に 期待できるものであれば，通知の「発信」および「到達」を認めてよいもの と思われる。

\section{（4）遺言による変更 一遺言の文言と受取人変更の有効性}

保険法 44 条 1 項は，遺言による受取人変更を認めるものであるが，遺言内 容如何によっては，受取人変更の効力が認められない場合もありうる。「全 財産を遺贈する」という文言や「保険金請求権を遺贈する」旨の遺言であれ ば，保険金受取人の変更の意思表示と解すべきではないかとする見解 ${ }^{57}$ があ る一方，大量の保険契約を取り扱う中で迅速・確実な保険金の支払いをしな ければならない保険者の立場としては，遺言の内容は客観的に明確に確認で きるものである必要があり, 受取人変更である旨が遺言に明示されていない

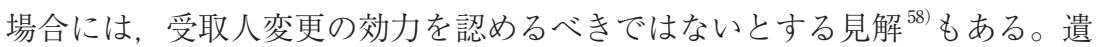
言において，どの程度保険金受取人変更であることが明示されていなければ ならないかという点は, 必ずしも明らかでなく，遺言による受取人変更を認 めた保険法の下でも引き続き検討されるべき課題である。

55）竹漬修「生命保険契約および傷害疾病契約特有の事項」ジュリ1364号43頁。

56）前掲注28) 保険法解説308頁〔山野嘉朗〕。

57）山下友信・前掲注3) 501頁。

58）矢野慎治郎「遺言による受取人変更」新しい保険法の理論と実務 130 頁（経 済法令研究会, 2008年)。 
保険金受取人に関する規定の理論的課題とその検討

遺言一般につき，その解釈基準は，最判昭和 58 年 3 月 18 日判時 1075 号 115 頁の判示内容に従っている。すなわち「遺言の解釈にあたつては，遺言書の 文言を形式的に判断するだけではなく，遺言者の真意を探究すべきものであ $り\lrcorner, 「$ 遺言書の全記載との関連，遺言書作成当時の事情及び遺言者の置かれ ていた状況などを考慮して遺言者の真意を探究し当該条項の趣旨を確定す心゙ きもの」とする。保険金受取人変更にあたって，しばしば問題となるのが 「全財産を遺贈する」，「保険金請求権を遺贈する」のような必ずしも受取人 変更である旨が明示されていない遺言につき，遺言者である保険契約者の真 意を探求することによって保険金受取人の変更を認めることができるかとい う点である。

従来の下級審裁判例では，その判断枠組みは必ずしも一貫しない。東京高

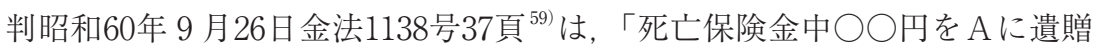
し，その余の遺産をすべて Bに遺贈する」旨の遺言につき，「被相続人の締 結した生命保険契約において保険金受取人として指定された特定の相続人が 生命保険金請求権を取得するのは，第三者のためにする保険契約の効果とし てであつて, 被相続人の有する保険金請求権を相続によつて承継取得するも のではなく，当該保険金請求権は受取人の固有の財産に属するものであつて, 相続財産を構成するものではないのであるから，被相続人は，特定の相続人 を保険金受取人として指定した以上，これを遺贈の目的とすることはできな いことはいうまでもなく，また，被相続人が受取人として指定された相続人 以外の第三者に保険金請求権を遺贈する旨の遺言をしても，それだけでは受 取人の変更としての効力を生じるものではない（商法六七七条一項参照）。」 として，本件遺言は，Aに遺贈するものとする限度において，無効というほ かない」と判示した。これは，保険金請求権の固有権性を根拠とするもので あり，遺言の解釈には踏み込んだものではない。

「全財産につき原告を相続人として指定する」旨の自筆証書遺言と「全財

59）大塚英明「判批」生命保険判例百選（増補版）（別冊ジュリ97号）216頁（有 斐閣，1988年)，長谷川宅司「判批」事例研レポ33号 1 頁。 
産を原告に遺贈する」旨の公正証書遺言による受取人変更の有効性が争われ た，名古屋高判平成13年 7 月 18 日生保判例集13巻573頁（名古屋地豊橋支判 平成12年11月 27 日同 12 巻 579 頁 $)^{60)}$ も基本的に同様であり, 保険金請求権の固 有財産性から，保険金請求権は保険契約者兼被保険者の財産から離脱してお り，遺言の「全財産」には含まれないと解さざるを得ないこと，保険金受取 人の変更であることが外部から明確に確認できるものでなければならないと 解されるところ，各各記載が保険金受取人変更の趣旨であることが明確であ るとはいえず，受取人変更の意思が外部から明確に確認できるとはいえない として, 受取人変更の効力を否定している。

他方で，最近の下級審裁判例においては，むしろ遺言内容につき，保険契 約者の最終的かつ確定的意思を尊重するために柔軟な解釈を行っているもの も少なくない。神戸地判平成15年 9 月 4 日生保判例集 15 巻543頁 ${ }^{61)}$ では, 「一 死亡生命保険（○○生命・ $\triangle \triangle$ 生命）の受取人を変更する。」一 右生命保 険のうち金一千万円をXに残す。」旨の自筆証書遺言（相続人でないXに対 する保険金受取人変更）につき，「確かに，本件遺言の記載は, 2 社との間に 生命保険契約があるにもかかわらず，そのどちらかを特定せず漠然と『一死 亡生命保険（○○生命・ $\triangle$ 生命）の受取人を変更する。』一 右生命保険 のうち金一千万円をXに残す。』とており，どちらの生命保険契約の受取 人を変更するものか, 明確でない点があることは否定できない」としながら も，その記載から推測される保険契約者兼被保険者の合理的意思を推測して， 「本件遺言の上記記載は, 本件(1)，(2)の生命保険契約の死亡保険金受取人の 変更につき，その内容を特定するに足りる記載と認めることができ」るとし て，「遺言による受取人の変更は，遺言者の死亡と同時に効力を生じ，遺言 のとおりに死亡保険金の受取人が変更されるものと認めるのが相当である」 と判示した。

60）評釈として, 岡田豊基「判批」事例研レポ 173 号 8 頁。

61）評釈として, 肥塚肇雄「判批」判夕1162号108頁, 山野嘉朗「判批」事例研 レポ193号 1 頁，山下典孝「判批」事例研レポ188号15頁。 
保険金受取人に関する規定の理論的課題とその検討

また, 京都地判平成18年 7 月 18 日生保判例集 18 巻489頁 ${ }^{62}$ は, 自己を被保 険者とする養老保険契約につき，保険金受取人の指定がなされていなかった が，公正証書遺言により，保険金が法的に遺産に含まれるか否かを問わず， Aが所有していた一切の財産をXに取得するつもりで，本件保険金について も受取人としてXを指定したと認定したうえで（遺言の具体的内容は不明）， 「少なくとも，遺言による保険金受取人指定の意思表示の有無が争点となる 保険金請求訴訟においては，裁判所がかかる意思表示の有無を事実認定する のであるから，その意思表示の明確性まで要求しなければならない必然性は そしく……, 他方, 本件のように公正証書遺言によってなされた保険契約者 の最終的・確定的意思を尊重しない結果となるのは妥当とはいえない。…... $\mathrm{A}$ の受取人指定の意思表示は外部から明確に認定できるといえる」として変 更の有効性を認めている。

東京地判平成21年 6 月 30 日2009WLJPCA06308039 ${ }^{63)}$ は, 受取人の指定の ない生命保険契約につき,「甲保険の保険金の全額を X（内縁の妻）が相続 すること」とする遺言書による受取人変更の有効性が争われた事案において, 遺言による受取人変更であると解釈した。遺言書の記載から，保険契約者兼 被保険者である「Aは，Xに対し，本件保険契約に係る保険金及び乙共済の 保険金の全額を取得させようとしていたことが明らかであり，自分が死亡し た場合に支払われる死亡保険金請求権を直接原告に取得させるという趣旨を， 遺言書の上で『相続する事』と表現したものと解するのが相当である」と判 示している。さらに，認定事実から「死亡保険金を，長年にわたり Aの生活 を支え，本件保険契約の保険料も支払い続けたXに取得させようとしたも の」であるとして，保険契約者と保険金受取人の生活実態をも保険契約者の 意思解釈に反映させている。

実務の現状としては，遺言において保険金受取人の変更であることが明確

62）山下典孝・前掲注43)43頁。

63）控訴審である東京高判平成 22 年 2 月 4 日生保判例集 22 巻 48 頁も同様。評釈と して，若林雅満「判批」事例研レポ250号 1 頁。 
でなければ，受取人の変更があったものとして死亡保険金の支払いに応じる ことは非常に難しくなっているとの指摘がある ${ }^{64)}$ 。しかしながら，このよう に，改正前商法下での裁判例ではあるものの，遺言による受取人変更につい ては, それが保険契約者の最終的かつ確定的な意思として, 外部から明確に 確認できるものである場合には，遺言の文言をできるかぎり柔軟に解釈をし て受取人変更と評価する余地があることを示唆する事例が少なくない ${ }^{65)}$ 。保 険金受取人変更の意思が「明確に」表示されたものとみることができるかは, 文言そのものではなく，事案の具体的状況に応じて判断されるべきものと思 われる。

(筆者は専修大学教授)

64）遠山優治「保険金受取人を巡る近時の裁判例・学説と実務の状況」生保論集 208 号11頁。

65）名古屋地一宮支判平成28年10月25日2016WLJPCA10256014（控訴審：名古 屋高判平成29年 4 月20日2017WLJPCA04206021。吉川良平「判批」共済と保 険2019年 7 ・ 8 月号41頁, 肥塚肇雄「判批」事例研レポ316号316頁）は, 生命 共済契約の契約者兼被共済者がその母を受取人に指定し, 契約者が営む事業の 従業員に「一切の財産を包括遺贈する」旨の自筆証書遺言がなされた事案にお いて, 本件遺言が受取人変更の趣旨でなされたものかについてはなんら触れる ことなく, 遺言の有効性ならびに受取人変更の有効性を認めるに至っている。 